\title{
A phenotypic comparison of yield and related traits in elite commercial corn hybrids resistant to pests
}

\author{
Comparación fenotípica del rendimiento y otras características \\ relacionadas en híbridos comerciales de maíz resistentes a plagas
}

Wilian Henrique Diniz Buso ${ }^{1}$; Leandro Lopes Gomes ${ }^{1}$; Paulina Ballesta2 ${ }^{2}$; Freddy Mora ${ }^{2}$

\begin{abstract}
The development of commercial maize hybrids tolerant to herbicide and resistant to lepidopterans has allowed an important expansion of this crop in Brazil. The objective of this study was to field-evaluate the performance of eleven maize hybrids at three different growing locations in Brazil to find adapted and stable hybrids. The fields were desiccated using glyphosate $\left(3 \mathrm{~L} \mathrm{ha}{ }^{-1}\right)$ seven days before seeding. Each trial was arranged in a randomized complete block design with four replications per location. In the joint analysis of eight agronomic traits, the error variances were considered heterogeneous among locations. The eleven hybrids presented significant differences in all traits. The hybrid DKB340PRO2 had the highest grain yield, which could be a recommended hybrid to local farmers. In addition, the hybrid $x$ location interaction was not statistically significant $(p>0.05)$, indicating stability of all the studied hybrids. Significant differences existed among the corn hybrids for eight agronomic traits, supporting our research hypothesis.
\end{abstract}

Key words: Grain yield, mixed model, thousand kernel weight, Zea mays.

\section{RESUMEN}

El desarrollo de híbridos comerciales de maíz tolerantes a herbicidas y resistentes a plagas ha permitido una importante expansión de este cultivo en Brasil. El objetivo de este estudio fue evaluar el desempeño de 11 híbridos comerciales de maíz en condiciones de campo, cultivados en tres localidades de Brasil, con el fin de identificar los híbridos mejor adaptados y estables. Los ensayos de campo fueron tratados con glifosato $\left(3 \mathrm{~L} \mathrm{ha}^{-1}\right)$ siete días antes de la siembra. Cada ensayo se estableció de acuerdo a un diseño de bloques completamente aleatorizados, con cuatro repeticiones por tratamiento. La evaluación agronómica de los 11 híbridos consideró ocho características de importancia agrícola. De acuerdo a los resultados, hubo diferencia significativa entre tratamientos para todas las características estudiadas. Particularmente, el híbrido DKB34OPRO2 obtuvo el mayor rendimiento de granos, por lo tanto, podría ser un híbrido recomendado para los productores locales. La interacción híbrido x sitio no fue significativa, lo cual implica que todos los híbridos estudiados tuvieron un desempeño estable.

Palabras clave: rendimiento en granos, modelos mixtos, peso de 1.000 granos, Zea mays.

\section{Introduction}

Corn (Zea mays L.) is one of the most important food crops worldwide. It is grown throughout the world with the United States, China, and Brazil being the top three maize-producing countries, harvesting approximately 563 of the 717 million metric tons/year (Ranum et al., 2014). In addition, this crop is considered a model system for the study of genetics, evolution, and domestication (Lu et al.,
2009). Brazilian maize genotypes have great diversity, consisting of varieties, families, single-cross, doublecross, and three-way hybrids (Duarte et al., 2005; Lopes et al., 2015; Rodovalho et al., 2014). In the global context, the genetic improvement in maize, combined with suitable agronomic practices, have allowed to increase the grain yield by an average of $111 \mathrm{~kg} \mathrm{ha}^{-1} \mathrm{yr}^{-1}$ between 1965 and 2012 (USDA, $2015)$., and the $60 \%$ of this increase has been attributed to production based on hybrids (Baldauf

1 Deparment of Zootechny and Agriculture, Goiano Federal Institute, Goias, Brazil.

2 University of Talca, Institute of Biological Sciences, 2 Norte 685, Talca, Chile.

* Corresponding author. 
et al., 2016). The maize industry has commercialized hybrid lines instead of pure lines because plants of a single-cross hybrid are generally more vigorous than the parental inbred plants.

Simple hybrid strategy is a cross between two pure inbreed-lines, in which parental lines are combined since each one brings agronomic traits of interest and the offspring can have the same or even higher breeding value than the parents (Solalinde et al., 2014). Notably, this strategy is the one of most common sources to obtain heterotic hybrids (Frascaroli et al., 2007). However, the development of single-cross hybrids is expensive, time consuming, and labor-intensive. Breeders have selected high-yielding hybrids of which some are resistant to biotic and abiotic stress and adaptable to different environments. For example, hybrid H-562 (Gómez et al., 2008) has been adapted to subtropical areas, which is not suitable for most exotic maize genotypes. The Brazilian hybrid DKXL370A is resistant to several insects (Ni et al., 2012) and Yuyu22 is a Chinese hybrid with relative environmental stability and exhibits a high level of heterosis on grain yield (Guo et al., 2013).

The success of the crops is also determined by cultural practices. Maize crops can be attacked by a wide range of insects. However, the resistance to insects is limited in maize. For this reason, transgenic hybrids (Bt Maize) have been produced to reduce the use of pesticides (Meissle et al., 2010). Transgenic Bt lines provide effective control for many key insect pests and reduce the use of conventional insecticides (Gassmann et al., 2012). Giles et al. (2000) created a hybrid transgenic maize (Bt) that was able to affect Plodia interpunctella (Lepidoptera) populations up to 4 or 5 months after harvest. The objective of this study was to assess the performance of commercial maize hybrids that are tolerant to glyphosate and resistant to five species of lepidopterans: Spodoptera frugiperda, Agrotis ipsilon, Diatraea saccharalis, Helicoverpa zea, and Elasmopalpus lignosellus. We hypothesized that differences for grain yield and related traits exist among the resistant hybrids, which could be useful information for corn growers when choosing specific hybrids for cultivation.

\section{Materials and methods}

\section{Plant material}

Eleven commercial hybrids (single-crosses) were selected according to the breeding companies' recommendations. Selected hybrids were fieldevaluated for eight agronomic traits at three different growing locations in Goiás State, Brazil. All hybrids are tolerant to glyphosate and resistant to five lepidopterans: Spodoptera frugiperda, Agrotis ipsilon, Diatraea saccharalis, Helicoverpa zea, and Elasmopalpus lignosellus. Table 1 summarizes the morphological properties (including seed company) of maize hybrids evaluated for yield and related traits in Brazil.

Table 1. Grain traits, maturity cycle and supplier company of commercial maize hybrids, which were field-evaluated for eight agronomic traits at three different growing locations of Brazil.

\begin{tabular}{lllll}
\hline \multicolumn{1}{c}{ Hybrid } & Grain texture & Grain color & Growth cycle & Seed company \\
\hline AGN30A91 PW* & Half-Hard & Orange & Early & Morgan \\
Truck VIP3 & Hard & Orange & Early & Syngenta \\
Impacto VIP3 & Hard & Orange & Early & Syngenta \\
Syn 7205 VIP3 & Hard & Orange & Early & Syngenta \\
MG580PW & Half-Hard & Yellow/Orange & Early & Morgan \\
MG652PW & Half-Hard & Yellow/Orange & Early & Morgan \\
DKB390PRO2 & Half-Hard & Yellow/Orange & Early & Dekalb \\
DKB310PRO2 & Half-Hard & Yellow/Orange & Half-Early & Dekalb \\
DKB340PRO2 & Half-Hard & Yellow/Orange & Half-Early & Dekalb \\
DKB290PRO3 & Dentate & Yellow/Orange & Half-Early & Dekalb \\
AG7098PRO2 & Half-Dentate & Yellow/Orange & Early & Agroceres \\
\hline
\end{tabular}

*Insect Resistance (IR) and herbicide tolerance (HT). Hybrids with PW technology (power core) have IR: Bt Cry1F + Cry1A.105 + Cry2Ab + HT (roundup ready technology); PRO2 have IR: Bt Cry1A.105 + Cry2Ab + HT (roundup ready technology); PRO3: IR (PRO2 + Bt Cry3A) and HT (roundup ready technology). 


\section{Field trials}

Field experiments were conducted in cooperation with private Brazilian breeding companies in the 2014-2015 growing season. The eleven corn hybrids were grown at three locations (Table 2) in the districts of Goiás, Brazil: Itapaci (Córrego do Oriente farm), Campinorte (Três Irmãos farm) and Itaberaí (KS agricultural) in no-tillage systems. Glyphosate $\left(3 \mathrm{~L} \mathrm{ha}^{-1}\right)$ was applied to the soil seven days before seeding. The treatments were seeded with $0.5 \mathrm{~m}$ between rows ( 3.3 seeds per meter, with a final stand of 60,000 plants ha $^{-1}$. Soil fertilization consisted in $20 \mathrm{~kg} \mathrm{ha}^{-1}$ of nitrogen, $150 \mathrm{~kg} \mathrm{ha}^{-1}$ of phosphor, and $50 \mathrm{~kg} \mathrm{ha}^{-1}$ potassium. Cover fertilization was done when the plants had at least five leaves, using $130 \mathrm{~kg} \mathrm{ha}^{-1}$ of nitrogen (urea). Glyphosate herbicide was applied again when the plants had at least six leaves.

\section{Experimental design and traits assessed}

Each trial was arranged according to a randomized complete block design with four replications per location. A plot consisted in two rows (of $5 \mathrm{~m}$ ) with four edge rows. The harvest was done on the following dates: 02/05/2015 (Itapaci), 09/05/2015 (Campinorte) and 04/05/2015 (Itaberaí). The following eight agronomic traits were evaluated in each location: stalk diameter (SD, in millimeters), plant height ( $\mathrm{PH}$, in meters), first ear height (FEH, in meters), ear diameter (ED, in millimeters), ear length (EL, in centimeters), number of kernels per row (NKR), one-thousand-kernel weight (TKW, in kilograms), and grain yield (GY, in kilograms per hectare). Grain yield values were corrected to $13 \%$ humidity.

\section{Phenotypic data analysis}

Previous analysis of heterogeneity of error variances among environments was performed using the likelihood ratio test, which indicated heterogeneous variances among trial locations. Therefore, in the combined analysis, error variances were considered heterogeneous among locations and were analyzed assuming the following statistical model:

$$
y=X \beta+Z w+\varepsilon
$$

where $\boldsymbol{y}$ is a vector of a continuous random variable, normally distributed, and refers to the agronomic variables. $\beta$ is a vector of the effects due to hybrids, environments, and hybrid-environment interaction. $w$ is a vector of block nested within the environment. $\varepsilon$ is an unobserved vector of residuals. $X$ and $Z$ are known incidence matrices. Error variances (heterogeneous) were estimated using Maximum Likelihood in the SAS software with REPEATED statement of the GLM procedure. The CORR procedure of SAS was used to estimate Pearson correlations between pairs of traits.

\section{Results and discussion}

The statistical analyses of fixed effects for the eight traits of interest are shown in Table 3. According to the F values (type III tests of fixed effects), significant differences were observed among the three locations for all traits. Mean values for all traits were highest in Itapaci. In the other locations, vegetative trait values $(\mathrm{SD}, \mathrm{PH}$, and $\mathrm{FEH})$ were higher in Itaberaí than Campinorte, while reproductive trait values (ED, EL, NKR, TKW, and GY) were higher in Campinorte. Environmental conditions may affect the development of reproductive and vegetative system structures in maize (Kakumanu et al., 2012; Storme and Geelen, 2014). In respect to reproductive traits, the highest average for GY, TKW, NKR, EL, and ED was $6,387 \mathrm{~kg} \mathrm{ha}^{-1}, 0.2 \mathrm{~kg}, 34.4$ kernels, $16.4 \mathrm{~cm}$, and $50.7 \mathrm{~mm}$, respectively, in the Itapaci district, while the lowest one was $4,707 \mathrm{~kg} \mathrm{ha}^{-1}$ (GY), $0.2 \mathrm{~kg}$ (TKW), 31.5 kernels (NKR), $14.4 \mathrm{~cm}$ $(\mathrm{EH})$, and $47.7 \mathrm{~mm}(\mathrm{ED})$ in Itaberaí district. On the other hand, the highest average for vegetative traits was $24 \mathrm{~mm}(\mathrm{SD}), 2.2 \mathrm{~m}(\mathrm{PH})$, and $1.3 \mathrm{~m}(\mathrm{FEH})$, and the lowest one was $15.6 \mathrm{~mm}(\mathrm{SD}), 1.6 \mathrm{~m}(\mathrm{PH})$, and $0.9 \mathrm{~m}(\mathrm{FEH})$ in the Campinorte district.

Table 2. Location of experimental trials in three districts of Goiás State, Brazil.

\begin{tabular}{llcc}
\hline \multirow{2}{*}{ Location } & \multicolumn{2}{c}{ Coordinates } & \multirow{2}{*}{ Altitude (m) } \\
\cline { 2 - 3 } & Latitude (S) & Longitude (W) & \\
\hline Itapaci (Córrego do Oriente) & 22 L 0661936 & 8339490 & 541 \\
Campinorte (Três Irmãos) & 22 L 0709409 & 8415240 & 514 \\
Itaberaí (KS Agricultural) & 22 L 0634456 & 8246462 & 713 \\
\hline
\end{tabular}


Table 3. Analysis of fixed effects of hybrid, location and hybrid $\mathrm{x}$ location interaction for eight traits measured in eleven commercial hybrids of corn (single-crosses).

Data are presented as phenotypic means with minimum and maximum values in parentheses

\begin{tabular}{lcccrrr}
\hline \multirow{2}{*}{ Trait } & \multicolumn{3}{c}{ Location } & \multirow{2}{*}{ Hybrid } & HSI & Location \\
\cline { 2 - 4 } & Itapaci & Campinorte & Itaberaí & & & \\
\hline SD (mm) & $24.0(20.0-27.4)$ & $15.6(13.5-18.0)$ & $17.2(13.5-22)$ & 0.07 & NS & $<0.01$ \\
PH (m) & $2.2(2.0-2.5)$ & $1.6(1.4-2.0)$ & $1.8(1.5-2.1)$ & $<0.01$ & 0.01 & $<0.01$ \\
FEH (m) & $1.3(1.1-1.5)$ & $0.9(0.7-1.2)$ & $1.0(0.7-1.2)$ & 0.01 & NS & $<0.01$ \\
ED (mm) & $50.7(45.1-55.6)$ & $49.6(44.9-54.5)$ & $47.7(43.8-53.9)$ & $<0.01$ & NS & $<0.01$ \\
EL (cm) & $16.4(14-20)$ & $15.3(12-18)$ & $14.4(11-18)$ & $<0.01$ & NS & $<0.01$ \\
NKR & $34.4(28-40)$ & $33.3(27-40)$ & $31.5(26-40)$ & $<0.01$ & NS & $<0.01$ \\
TKW (kg) & $0.17(0.15-0.19)$ & $0.2(0.17-0.21)$ & $0.16(0.14-0.19)$ & 0.05 & NS & $<0.01$ \\
GY $\left(\mathrm{kg} \mathrm{ha}^{-1}\right)$ & $6,387(4,970-7,640)$ & $5,890(4,368-7,755)$ & $4,707(2,786-6,865)$ & $<0.01$ & NS & $<0.01$ \\
\hline
\end{tabular}

SD: Stalk diameter, PH: plant height, FEH: first ear height, ED: ear diameter, EL: ear length, NKR: number of kernels per row, TKW: one-thousand kernel weight, GY: grain yield, HSI: hybrid x location interaction, NS: Non-significant.

The eleven hybrids presented significant differences in all traits under study. Therefore, some hybrids achieved superior performance probably due to the inherent genetic variation. On the other hand, SD mean values were statistically different at $p<0.07$ among hybrids. Reproductive traits usually have higher heritability than vegetative traits (Ortiz et al., 2008). Even agronomic traits such as NKR, TKW, and EL have higher heritability than GY. In fact, GY has shown to be a poorly heritable trait and typically sensitive to climatic conditions. In addition, hybrid $\mathrm{x}$ location interaction effect was not statistically significant in most traits under study. In this context, the results obtained are useful for corn improvement due to a significant genotype-environment interaction that reduces the selection efficiency (Fan et al., 2007). Beyene et al. (2011) proposed a genotype plus genotype by the environment interaction approach (GGE), which allowed identifying two stable hybrids across different environments. In addition, these identified genotypes were highly desirable in terms of grain yield. On other hand, hybrid x location interaction effect was statistically significant in $\mathrm{PH}$. A genomic selection study reported a significant genotype-environment interaction in agronomic traits such as grain yield, plant height, and starch content (Wang et al. 2014).

The comparative analysis of hybrid performances for each trait under study is shown in Table 4. The results revealed that EL and NKR were the most variable traits, while the traits TKW and SD

Table 4. Phenotypic analysis of yield and related traits in eleven commercial maize hybrids with resistance to herbicide and insect feeding pressure.

\begin{tabular}{lllllllll}
\hline \multicolumn{1}{c}{ Hybrid } & \multicolumn{1}{c}{ SD } & PH & \multicolumn{1}{c}{ FEH } & ED & \multicolumn{1}{c}{ EL } & \multicolumn{1}{c}{ NKR } & TKW & GY \\
\hline AGN30A91 PW & $18.0 \mathrm{bc}$ & $1.80 \mathrm{~d}$ & $0.99 \mathrm{~cd}$ & $49.6 \mathrm{bc}$ & $15.0 \mathrm{de}$ & $33.3 \mathrm{bcd}$ & $0.173 \mathrm{abc}$ & $5,442 \mathrm{c}$ \\
Truck VIP3 & $18.6 \mathrm{bc}$ & $1.82 \mathrm{~d}$ & $1.04 \mathrm{bcd}$ & $47.8 \mathrm{de}$ & $15.7 \mathrm{bcd}$ & $33.8 \mathrm{bc}$ & $0.176 \mathrm{ab}$ & $5,772 \mathrm{bc}$ \\
Impacto VIP3 & $18.5 \mathrm{bc}$ & $1.84 \mathrm{~cd}$ & $1.04 \mathrm{bcd}$ & $48.7 \mathrm{~cd}$ & $15.1 \mathrm{cde}$ & $30.9 \mathrm{f}$ & $0.174 \mathrm{abc}$ & $5,259 \mathrm{c}$ \\
Syn 7205 VIP3 & $18.8 \mathrm{abc}$ & $1.84 \mathrm{~cd}$ & $0.98 \mathrm{~d}$ & $50.2 \mathrm{bc}$ & $14.7 \mathrm{e}$ & $32.2 \mathrm{cdef}$ & $0.171 \mathrm{bc}$ & $5,268 \mathrm{c}$ \\
MG580PW & $19.2 \mathrm{ab}$ & $1.80 \mathrm{~d}$ & $0.99 \mathrm{~cd}$ & $48.8 \mathrm{~cd}$ & $15.3 \mathrm{cde}$ & $33.5 \mathrm{bc}$ & $0.174 \mathrm{abc}$ & $5,615 \mathrm{c}$ \\
MG652PW & $20.1 \mathrm{a}$ & $1.84 \mathrm{~cd}$ & $1.06 \mathrm{bc}$ & $51.0 \mathrm{ab}$ & $15.6 \mathrm{bcd}$ & $34.5 \mathrm{ab}$ & $0.175 \mathrm{abc}$ & $5,697 \mathrm{c}$ \\
DKB390PRO2 & $19.2 \mathrm{ab}$ & $1.90 \mathrm{bc}$ & $1.10 \mathrm{ab}$ & $49.5 \mathrm{c}$ & $16.3 \mathrm{ab}$ & $33.8 \mathrm{bc}$ & $0.174 \mathrm{abc}$ & $6,394 \mathrm{ab}$ \\
DKB310PRO2 & $19.4 \mathrm{ab}$ & $1.95 \mathrm{~b}$ & $1.11 \mathrm{ab}$ & $49.1 \mathrm{~cd}$ & $13.8 \mathrm{f}$ & $31.4 \mathrm{def}$ & $0.180 \mathrm{a}$ & $5,495 \mathrm{c}$ \\
DKB340PRO2 & $19.2 \mathrm{ab}$ & $2.04 \mathrm{a}$ & $1.15 \mathrm{a}$ & $46.9 \mathrm{e}$ & $16.8 \mathrm{a}$ & $33.3 \mathrm{bcde}$ & $0.180 \mathrm{a}$ & $6,450 \mathrm{a}$ \\
DKB290PRO3 & $19.3 \mathrm{ab}$ & $1.93 \mathrm{~b}$ & $1.04 \mathrm{bcd}$ & $48.9 \mathrm{~cd}$ & $15.9 \mathrm{abc}$ & $35.9 \mathrm{a}$ & $0.168 \mathrm{c}$ & $5,226 \mathrm{c}$ \\
AG7098PRO2 & $17.8 \mathrm{c}$ & $1.95 \mathrm{~b}$ & $1.11 \mathrm{ab}$ & $52.3 \mathrm{a}$ & $14.8 \mathrm{de}$ & $31.3 \mathrm{ef}$ & $0.172 \mathrm{bc}$ & $5,652 \mathrm{c}$ \\
\hline
\end{tabular}

* Means followed by the same letter are not significantly different at the 0.05 level. SD: Stalk diameter, PH: plant height, FEH: first ear height, ED: ear diameter, EL: ear length, NKR: number of kernels per row, TKW: one-thousand kernel weight, GY: grain yield. 
were the least contrasting among hybrids, which is in accordance with the analysis of fixed effects (Table 3). The hybrid DKB340PRO2 had the highest mean value for PH, FEH, TKW, EL, and GY. Only this hybrid was superior in more than one trait. The highest mean value for SD, ED, and NKR was reported in the hybrid MG652PW (20.1 mm), AG7098PRO2 (52.3 mm), and DKB290PRO3 (35.9 kernels), respectively; while the lowest values for $\mathrm{SD}, \mathrm{ED}$, and NKR were exhibited in AG7098PRO2 (17.8 mm), DKB340PRO2 (46.9 mm), and Impacto VIP3 (30.9 kernels), respectively.

Estimates of phenotypic correlations among traits are shown in Table 5. Grain yield was positively and significantly correlated with all traits. EL was the most correlated trait with $\mathrm{GY}(\mathrm{r}=0.61)$. Previous studies have reported a positive correlation between GY and KRN (Nemati et al., 2009), PH (Ilker, 2011; Yin et al., 2011), ED (Rafiq et al., 2010; Nemati et al., 2009), EL (Ilker, 2011), and TKW (Yusuf, 2010).

TKW was positively correlated with GY and it was the only trait negatively correlated with the vegetative traits (PH, SD, and FEH). However, Nemati et al. (2009) reported that TKW was negatively correlated with NKR and EL, which are reproductive traits. In addition, TKW was not significantly correlated with the other reproductive traits. In our study, vegetative traits were highly correlated among one another $(\mathrm{r}=$ $0.84,0.78$ and 0.92 ). The estimated correlations were moderately reflected in the hybrid performances. For instance, the hybrids DKB340PRO2 and AG7098PRO2 had a high value for PH and FEH, which is according to the estimated correlation (PH x FEH: $r=0.92$ ), while MG580pw consistently had a low value for $\mathrm{PH}$ and $\mathrm{FEH}$.

According to Pinnisch et al. (2012), grain yield, 1000-kernel weight, ear length, and kernel morphology are traits that are important in determining the suitability of a genotype (e.g. inbred line) for use as a seed parent in a seed production field. The high-yield hybrid DKB340PRO2 had the highest mean value for TKW, EL, FEH, and PH, however, it had the lowest mean for ED, and regular NKR. In contrast, low-yield hybrid DKB290PRO3 had the lowest mean value for TKW, regular for EL, high for NKR, moderately-low for FEH, and regular for PH. Higher mean values of TKW and EL were related to higher yield, while higher mean values of NKR were related to lower yield. However, all traits were positively correlated to GY. In addition, EL and NKR had a positive correlation. Therefore, TKW could have a major contribution in grain yield since it did not correlate with other reproductive traits (EL, NKR, and ED). In fact, based on genotypic correlation coefficients, Rafiq et al. (2010) found a significant correlation between 1000-kernel weight and grain yield in inbred lines of maize. In contrast, Pinnisch et al. (2012) found that ear length appeared to make a greater contribution to grain yield than 1000-kernel weight among maize inbred lines.

\section{Conclusions}

The hybrid DKB340PRO2 had the highest grain yield, which could be a promising and recommended hybrid to local farmers. The hybrid $x$ location interaction was not statistically significant, which indicates that the stability of the hybrids is not influenced by the studied environments. In addition, reproductive traits are the best predictor to select higher grain yields such as 1000-kernel weight and ear length. Finally, the hypothesis that differences for eight agronomic traits exist among the resistant hybrids was supported in this study.

Table 5. Pearson correlation coefficients among traits measured in eleven commercial corn hybrids with resistance to herbicide and insect feeding pressure.

\begin{tabular}{lcccccccc}
\hline \multicolumn{1}{c}{ Trait } & SD & PH & FEH & ED & EL & NKR & TKW & GY \\
\hline Stalk diameter (SD) & 1 & & & & & & & \\
Plant height (PH) & $0.84^{* *}$ & 1 & & & & & & \\
First ear height (FEH) & $0.78^{* *}$ & $0.92^{* *}$ & 1 & & & & & \\
Ear diameter (ED) & $0.31^{* *}$ & $0.28^{* *}$ & $0.26^{* *}$ & 1 & & & & \\
Ear lenght (EL) & $0.43^{* *}$ & $0.41^{* *}$ & $0.36^{* *}$ & $0.29 * *$ & 1 & & & \\
Kernels per row (NKR) & $0.31^{* *}$ & $0.24^{* *}$ & 0.17 & $0.31^{* *}$ & $0.74 * *$ & 1 & & \\
1,000 kernel weight (TKW) & $-0.28^{* *}$ & $-0.26^{* *}$ & $-0.24^{* *}$ & 0.12 & 0.13 & 0.12 & 1 & \\
Grain yield (GY) & $0.42^{* *}$ & $0.45^{* *}$ & $0.39^{* *}$ & $0.40^{* *}$ & $0.61 * *$ & $0.43^{* *}$ & $0.38^{* *}$ & 1 \\
\hline
\end{tabular}

** Significant at the 0.01 probability level. 


\section{Literature Cited}

Baldauf, J.A.; Marcon, C.; Paschold, A.; Hochholdinger, F. 2016. Nonsyntenic genes drive tissue-specific dynamics of differential, nonadditive, and allelic expression patterns in maize hybrids. Plant physiology, 171 (2): 1144-1155.

Beyene, Y.; Mugo, S.; Mutinda, C.; Tefera, T.; Karaya, H.; Ajanga, S.; Kega, V.

2011. Genotype by environment interactions and yield stability of stem borer resistant maize hybrids in Kenya. African Journal of Biotechnology, 10 (23): 4752-4758.

Duarte, A.P., Mason, S.C., Jackson, D.S., Kiehl, J.C. 2005. Grain quality of Brazilian maize genotypes as influenced by nitrogen level. Crop Science, 45 (5): 1958-1964.

Frascaroli, E.; Canè, M.A.; Landi, P.; Pea, G.; Gianfranceschi, L.; Villa, M.; Morgante, M.; Pè, M.E.

2007. Classical genetic and quantitative trait loci analyses of heterosis in a maize hybrid between two elite inbred lines. Genetics, 176 (1): 625-644.

Fan, X.M.; Kang, M.S.; Chen, H.; Zhang, Y.; Tan, J.; XU, C. 2007. Yield stability of maize hybrids evaluated in multienvironment trials in Yunnan, China. Agronomy Journal, 99 (1): 220-228.

Gassmann, A.J.; Petzold-Maxwell, J.L.; Keweshan, R.S.; Dunbar, M.W.

2012. Western corn rootworm and Bt maize: challenges of pest resistance in the field. GM crops \& food, 3 (3): 235-244.

Giles, K.L.; Hellmich, R.L.; Iverson, C.T.; Lewis, L.C. 2000. Effects of transgenic Bacillus thuringiensis maize grain on $B$. thuringiensis-susceptible Plodia interpunctella (Lepidoptera: Pyralidae). Journal of economic entomology, 93 (3): 1011-1016

Gómez, M.N.O.; Macías, M.S.; Camarillo, M.G.; Almaguer, M.Á.C.; Fonseca, A.R.; Pérez, J.J.W.; Salgado, M.M.; Díaz,

J.L.R.; Calderón, A.E.

2008. H-562, híbrido de maíz de alto rendimiento para el trópico húmedo y seco de México. Agricultura técnica en México, 34 (1): 101-105.

Guo, T.; Li, H.; Yan, J.; Tang, J.; Li, J.; Zhang, Z.; Wang, J.

2013. Performance prediction of $F 1$ hybrids between recombinant inbred lines derived from two elite maize inbred lines. Theoretical and applied genetics, 126 (1): 189-201.

Ilker, E.

2011. Correlation and path coefficient analyses in sweet corn. Turkish Journal of Field Crops, 16 (2): 105-107.

Kakumanu, A.; Ambavaram, M.M.; Klumas, C.; Krishnan, A.;

Batlang, U.; Myers, E.; Grene, R.; Pereira, A.

2012. Effects of drought on gene expression in maize reproductive and leaf meristem tissue revealed by RNASeq. Plant Physiology, 160 (2): 846-867.

Lopes, A.D.; Scapim, C.A.; Machado, M.F.P.S.; Mangolim, C.A.; Silva, T.A.; Cantagali, L.B.; Teixeira, F.F.; Mora, F.

2015. Genetic diversity assessed by microsatellite markers in sweet corn cultivars. Scientia Agricola, 72 (6): 513-519.

Lu, Y.L.; Yan, J.; Guimarães, C.T.; Taba, S.; Hao, Z., Gao, S.; Chen, S., Li, J.; Zhang, S.; Vivek, B.S.; Magorokosho, C.; Mugo, S.; Makumbi, D.; Parentoni, S.N.; Shah, T.; Rong, T.; Crouch, J.H.; Xu, Y.

2009. Molecular characterization of global maize breeding germplasm based on genome-wide single nucleotide polymorphisms. Theoretical and Applied Genetics, 120 (1): 93-115.

Meissle, M.; Mouron, P.; Musa, T.; Bigler, F.; Pons, X.; Vasileiadis, V.P.; Otto, S.; Antichi, D.; Kiss, J.; Pálinkás, Z.; Dorner, Z.;
Van Der Weide, R.; Groten, J.; Czembor, E.; Adamczyk, J.; Thibord, J.B.; Melander, B.; Cordsen Nielsen, G.; Poulsen, R.T.; Zimmermann, O.; Verschwele, A.; Oldenburg, E.

2010. Pests, pesticide use and alternative options in European maize production: current status and future prospects. Journal of Applied Entomology, 134 (5): 357-375.

Nemati, A.; Sedghi, M.; Sharifi, R.S.; Seiedi, M.N.

2009. Investigation of correlation between traits and path analysis of corn (Zea mays L.) grain yield at the climate of Ardabil region (Northwest Iran). Notulae Botanicae Horti Agrobotanici Cluj-Napoca, 37 (1): 194-198.

Ni, X.; Xu, W.; Blanco, M.H.; Wilson, J.P.

2012. Evaluation of corn germplasm lines for multiple ear-colonizing insect and disease resistance. Journal of economic entomology, 105 (4): 1457-1464.

Ortiz, R.; Crossa, J.; Sevilla, R.

2008. Minimum resources for phenotyping morphological traits of maize (Zea mays L.) genetic resources. Plant Genetics Resources, 6 (3): 195-200.

Pinnisch, R.; Mowers, R.; Trumpy, H.; Walejko, R.; Bush, D. 2012. Evaluation of maize (Zea mays L) inbred lines for yield component traits and kernel morphology. Maydica, 57 (1): $1-5$.

Rafiq, M.; Rafique, M.; Hussain, A.; Altaf, M.

2010. Studies on the heritability, correlation and path analysis in maize (Zea mays L). Journal Agricultural Research, 48 (1): 35-38.

Ranum, P.; Peña-Rosas, J.P.; Garcia-Casal, M.N.

2014. Global maize production, utilization and consumption. Annals of the New York Academy of Sciences, 1312 (1): 105-112.

Rodovalho, M.; Mora, F.; Scapim, C.A.; Arriagada, O.; Maldonado, C. 2014. Genetic evaluation of popcorn families using a Bayesian approach via the independence chain algorithm. Crop Breeding and Applied Biotechnology, 14 (4): 261-265.

Solalinde, J.M.Q.; Scapim, C.A.; Vieira, R.A.; do Amaral, A.T.J.; Vivas, M.; Pinto, R.J.B.; Mora, F.; Viana, A.P.

2014. Performance of popcorn maize populations in South American Avatí Pichingá using diallel analysis. Australian Journal of Crop Science, 8 (12): 1632-1638.

Storme, N.; Geelen, D.

2014. The impact of environmental stress on male reproductive development in plants: biological processes and molecular mechanisms. Plant, cell \& environment, 37 (1): 1-18.

USDA

2015. Crop production historical track records. National Agriculture Statistics Service, Washington, DC.

Wang, Y.; Mette, M.F.; Miedaner, T.; Gottwald, M.; Wilde, P.; Reif, J.C.; Zhao, Y.

2014. The accuracy of prediction of genomic selection in elite hybrid rye populations surpasses the accuracy of marker-assisted selection and is equally augmented by multiple field evaluation locations and test years. $B M C$ genomics, 15 (1): 556.

Yin, X.; Mcclure, M.A.; Jaja, N.; Tyler, D.D.; Hayes, R.M.

2011. In-season prediction of corn yield using plant height under major production systems. Agronomy Journal, 103 (3): 923-929.

Yusuf, $\mathrm{M}$.

2010. Genetic variability and correlation in single cross hybrids of quality protein maize (Zea mays L.). African Journal of Food, Agriculture, Nutrition and Development 10 (2): 2166-2175. 